\title{
EFEKTIFITAS PENGGUNAAN KOMBINASI METODE BASOKU DAN POLA MAKAN TERHADAP PENINGKATAN PRODUKSI ASI DI PMB SANTI YOSINA KECAMATAN SYAMTALIRA BAYU KABUPATEN ACEH UTARA
}

\author{
Khalidah $^{1}$, Eka Sutrisna ${ }^{2}$ \\ STIKes Getsempena Lhoksukon \\ khalidahdah@yahoo.com, ekasutrisna84@gmail.com
}

\begin{abstract}
Smooth milk production is very important to meet the baby's nutritional and nutritional needs. One of the most effective methods to increase milk production and reduce mother's stress while breastfeeding is to combine the BASOKU method (breastcare, oxytocin massage and husband's support) and regulate diet. The aim of the study was to determine the effectiveness of the combination of the BASOKU method and diet on increasing breast milk production at PMB Santi Yosina, Syamtalira Bayu District, North Aceh Regency. Quasi research or experimental experiment with a Two - Group Posttest Only design. The population of this study were all postpartum mothers who gave birth at PMB Santi Yosina. The sample in this study used purposive sampling as many as 17 people in the control group and 17 people in the treatment group. Data were analyzed using paired t-test. The study was conducted from April to September 2021. The results of the univariate analysis showed that most of the increase in breast milk production in postpartum mothers in the intervention group in the 140-200 gram category was 15 people (88.2\%) while in the control group in the <140 category. grams by 14 people (82.4\%). The results of the bivariate analysis showed that there was a difference between the combined use of the BASOKU method on increasing breast milk production in postpartum mothers with a $p$ value of 0.000. Suggestions for respondents can apply the BASOKU method and diet to increase milk production.
\end{abstract}

Keywords $\quad$ : BASOKU Method, Diet, Breast Milk Production.

\begin{abstract}
ABSTRAK
Kelancaran produksi ASI sangat penting untuk memenuhi kebutuhan nitrisi dan gizi bayi. Salah satu metode yang paling efektif untuk meningkatkan produksi ASI dan mengurangi stres ibu saat menyusui adalah dengan melakukan kombinasi metode BASOKU (breastcare, pijat oksitosin dan dukungan suami) serta mengatur pola makan. Tujuan penelitian untuk Efektifitas Penggunaan Kombinasi Metode BASOKU dan Pola Makan Terhadap Peningkatan Produksi ASI di PMB Santi Yosina Kecamatan Syamtalira Bayu Kabupaten Aceh Utara. Penelitian semu atau guasy eksperiment dengan rancangan Two - Group Postes Only. Populasi penelitian ini adalah seluruh ibu nifas yang bersalin di PMB Santi Yosina. Sampel pada penelitian ini menggunakan purposive sampling yaitu sebanyak 17 orang kelompok kontrol dan 17 orang kelompok perlakuan. Data dianalisis menggunakan uji paired t-test. Penelitian telah dilakukan dari bulan April s/d September 2021. Hasil analisis univariat diperoleh bahwa sebagian besar peningkatan produksi ASI pada ibu nifas kelompok intervensi pada kategori 140 -200 gram sebesar 15 orang $(88,2 \%)$ sedangkan pada kelompok kontrol pada kategori $<140$ gram sebesar 14 orang $(82,4 \%)$. Hasil analisis bivariat diperoleh bahwa terdapat perbedaan antara penggunaan kombinasi metode BASOKU terhadap peningkatan poduksi ASI pada ibu nifas dengan nilai $p$ value 0.000. Saran bagi responden dapat menerapkan metode BASOKU dan pola makan untuk meningkatkan produksi ASI.
\end{abstract}

Kata Kunci : Metode BASOKU, Pola Makan, Produksi ASI. 


\section{PENDAHULUAN}

Air Susu Ibu (ASI) ekslusif adalah makanan terbaik bagi bayi. Kandungan nutrisi dan zat gizi terdapat didalam ASI yang berguna bagi perkembangan dan pertumbuhan bayi yang optimal. Bayi yang diberikan ASI memiliki resiko yang kecil untuk menderita penyakit dan kekebalan tubuh yang meningkat, karena ASI mengandung sel darah putih, zat kekebalan tubuh bayi dan protein yang tinggi. Komposisi ASI yang sangat lengkap tidak dapat tergantikan dengan makanan lainnya, termasuk susu formula. Pemberian ASI eksklusif selalu mengalami hambatatan dikarenakan ASI tidak keluar setelah bersalin, tidak adanya puting susu, kesulitan bayi saat menghisap, promosi susu formula, ibu bekerja dan produksi ASI yang kurang serta stres dan cemas pada ibu yang beranggapan ASI nya tidak mencukupi kebutuhan bayinya (Kumala, F \& Rini, S. 2017).

Bagi seorang ibu menyusui merupakan kewajiban yang harus dijalankan, karena kelancaran produksi ASI sangat penting untuk memenuhi kebutuhan nitrisi dan gizi bayi. Salah satu metode yang paling efektif untuk meningkatkan produksi ASI dan mengurangi stres ibu saat menyusui adalah dengan melakukan kombinasi metode BASOKU (breastcare, pijat oksitosin dan dukungan suami) serta mengatur pola makan. Metode ini yakni dengan melakukan pemijatan payudara, pijat oksitosin pada tulang belakang sebagai upaya pengeluaran hormon oksitosin yang dapat merangsang produksi ASI yang lebih banyak, ditambah lagi dengan dukungan suami dalam pemberian ASI eksklusif pada bayinya, dengan adanya dukungan suami ibu akan merasa nyaman dan rileks dalam pemberian ASI (Aziziah \& Nisak 2019).

Perawatan yang efektif untuk memperbanyak produksi ASI adalah dengan perawatan payudara (breastcare) dengan menjaga kebersihan dan masage (pemijatan) payudara, senam payudara yang bertujuan melancarkan sirkulasi darah dan mencegah tersumbatnya saluran produksi ASI sehingga ASInya lancar. Pijat oksitosin merupakan salah satu solusi mengatasi ketidaklancaran produksi ASI yaitu dengan memijat pada tulang punggung belakang yang membuat ibu rileks, nyaman dan santai serta merangsang hormon oksitosin (Widiyanti, 2014).

Pengaturan pola makan ibu yang dapat meningkatkan produksi ASI yaitu dengan mengkonsumsi makanan yang dapat meningkatkan produksi ASI, salah satu cara meningkatkan produksi ASI yaitu dengan melakukan pola makan yang baik seperti makan teratur, tercukupi dan bergizi. Cara ibu untuk meningkatkan produksi ASI dengan pola makan yaitu dengan memperhatikan pola makan seperti makan tepat waktu dan mengkonsumsi makanan secukupnya berupa sayuran, daging, kacang-kacangan, buah-buahan, susu dan air putih (Sanima, 2017).

Hasil penjajakan awal yang peneliti lakukan pada 10 orang ibu nifas di PMB Santi Yosina, hanya $2(20 \%)$ ibu yang pernah menggunakan kombinasi metode BASOKU dan pola makan dan mereka mengatakan produksi ASI mereka lancar dan tetap dapat memberikan ASI eksklusif, karena ASInya yang berlimpah, berat badan bayi juga mengalami kenaikan 140-200 gram perminggu. Sedangkan $8(80 \%)$ ibu mengatakan tidak menggunakan metode BASOKU dan pola makan yang baik karena mereka tidak mengerti tentang metode ini dan apa manfaatnya untuk menyusui, produksi ASI sedikit dan kurang lancar, sehingga harus dibantu dengan susu formula untuk mencukupi kebutuhan bayinya.

Berdasarkan hal tersebut peneliti tertarik meneliti Efektifitas Penggunaan Kombinasi Metode BASOKU dan Pola Makan Terhadap Peningkatan Produksi ASI di PMB Santi Yosina Kecamatan Syamtalira Bayu Kabupaten Aceh Utara. 


\section{METODE}

Jenis penelitian ini adalah kuantitatif. Metode Penelitian yang digunakan adalah penelitian semu atau guasy eksperiment dengan rancangan Two - Group Postes Only yang bertujuan untuk mengetahui penggunaan metode BASOKU dan pola makan terhadap peningkatan produksi ASI pada ibu nifas di PMB Santi Yosina, Amd. Keb Kecamatan Syamtalira Bayu Kabupaten Aceh Utara. Metode rancangannya adalah sebagai berikut.

\section{HASIL}

\section{Peningkatan Produksi ASI pada Ibu Nifas}

Berdasarkan hasil penelitian peningkatan produksi ASI pada ibu nifas, secara rinci terlihat dalam tabel berikut ini:

Tabel 1. Distribusi Frekuensi Peningkatan Produksi ASI pada Ibu Di PMB Santi Yosina, Amd.Keb Kecamatan Syamtalira Bayu

\begin{tabular}{llcccc}
\hline $\mathrm{N}$ & Peningkatan & \multicolumn{2}{c}{ Kelompok } & \multicolumn{2}{c}{ Kelompok } \\
$\mathrm{O}$ & Produksi ASI & \multicolumn{2}{c}{ Intervensi } & \multicolumn{2}{c}{ Kontrol } \\
\cline { 3 - 6 } & pada Ibu Nifas & $\mathrm{F}$ & $\%$ & $\mathrm{~F}$ & $\%$ \\
\hline 1 & $140-200$ gram & 15 & 88,2 & 3 & 17,6 \\
2 & $<140$ gram & 2 & 11,8 & 14 & 82,4 \\
& & 2 & & & \\
\hline & Total & 17 & 100 & 17 & 100 \\
\hline
\end{tabular}

Sumber : Data Primer, 2021)

Dari tabel 1 dapat dilihat bahwa peningkatan produksi ASI pada ibu nifas kelompok intervensi di PMB Santi Yosina, Amd.Keb Kecamatan Syamtalira Bayu Kabupaten Aceh Utara tahun 2021, sebagian besar berada pada kategori 140200 gram yaitu sebanyak 15 orang dengan persentase $88,2 \%$ sedangkan peningkatan produksi ASI pada ibu nifas kelompok kontrol sebagian besar berada pada kategori
$<140$ gram yaitu sebanyak 14 orang dengan persentase $82,4 \%$.

\section{Uji Normalitas Data}

Tabel 2.Hasil Uji Normalitas Data

\begin{tabular}{llll}
\hline Kelompok & $\begin{array}{l}p- \\
\text { value }\end{array}$ & $\rho-\alpha$ & Kriteria \\
\hline $\begin{array}{l}\text { Peningkatan } \\
\text { Produksi ASI } \\
\text { Intervensi }\end{array}$ & 0.2 & 0.05 & $\begin{array}{l}\text { Berdistribusi } \\
\text { Normal }\end{array}$ \\
\hline Kontrol & 0.2 & 0.05 & $\begin{array}{l}\text { Berdistribusi } \\
\text { Normal }\end{array}$ \\
\hline
\end{tabular}

Dari tabel 2 dapat dilihat bahwa data berdistribusi normal, hal tersebut dibuktikan dengan nilai signifikan masingmasing data >

0.05 sehingga disimpulkan data berdistribusi normal, selanjutnya untuk uji bivariat jika data numerik berdistribusi normal menggunakan statistik parametrics dengan uji independent t-test.

\section{Penggunaan Kombinasi Metode BASOKU dan Pola Makan terhadap Peningkatan Produksi ASI pada Ibu Nifas}

Uji penggunaan kombinasi merode BASOKU dan pola makan terhadap peningkatan produksi ASI pada ibu nifas di PMB Santi Yosina, Amd.Keb Kecamatan Syamtailra Kabupaten Aceh Utara disajikan dalam tabel 3.

Dari tabel 3 menunjukkan bahwa hasil analisis statistik uji-t test didapatkan hasil nilai $\mathrm{t}$ hitung $>\mathrm{t}$ tabel $(2.394>2.037)$ dan nilai $p$ sebesar $0.000<0.05$ maka diambil keputusan menolak Ho dan menerima Ha, sehingga dapat disimpulkan terdapat perbedaan penggunaan kombinasi metode BASOKU dan Pola Makan terhadap peningkatan produksi ASI pada ibu nifas di PMB Santi Yosina, Amd.Keb Kecamatan Syamtailra Kabupaten Aceh Utara. 
Tabel 3. Hasil Uji penggunaan kombinasi merode BASOKU dan pola makan terhadap peningkatan produksi ASI pada ibu nifas di PMB Santi Yosina, Amd.Keb Kecamatan Syamtailra Kabupaten Aceh Utara

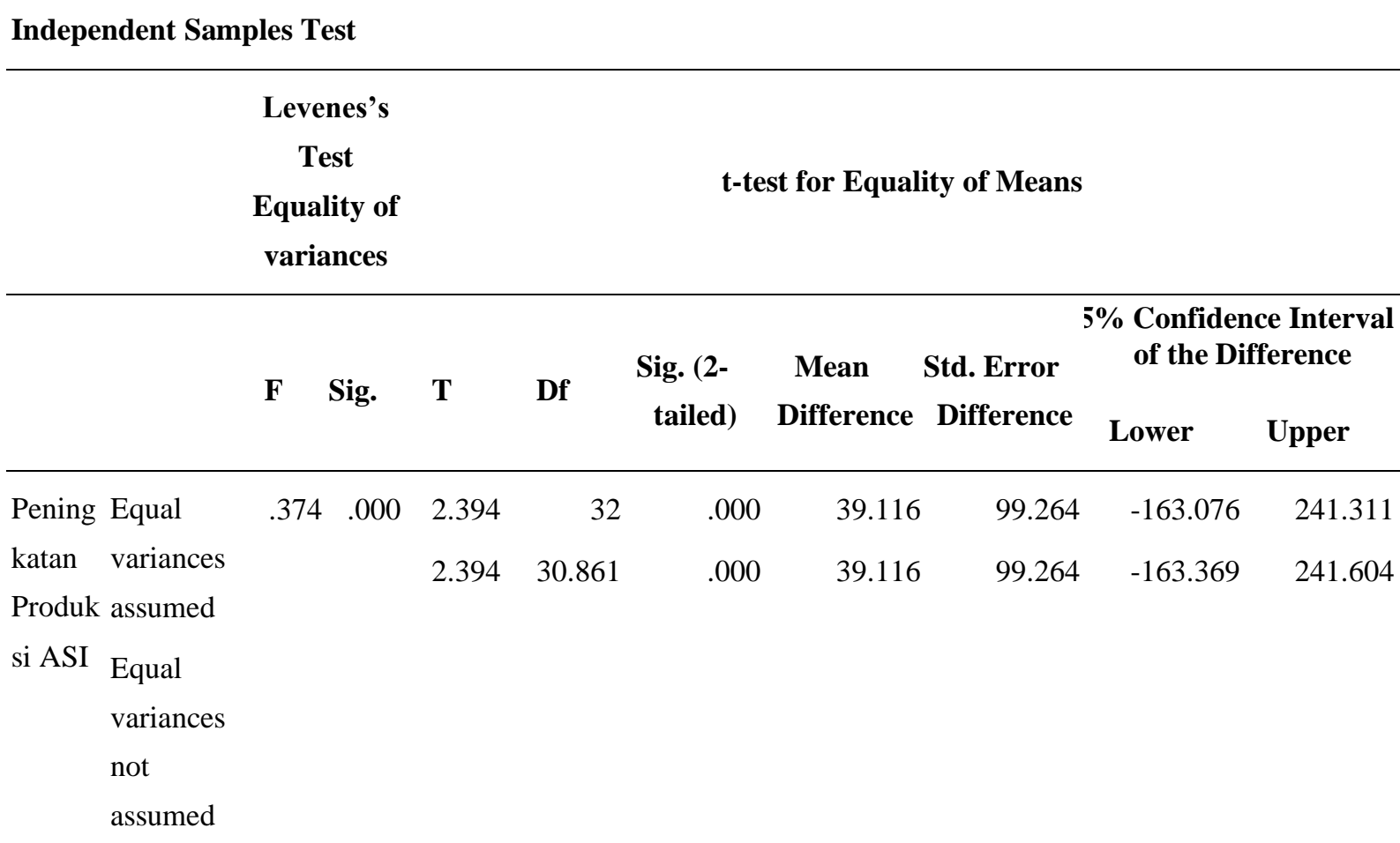

\section{PEMBAHASAN}

\section{Peningkatan Produksi ASI pada Ibu} Nifas

Dari hasil penelitian didapatkan bahwa distribusi frekuensi tertinggi kelompok intervensi berdasarkan peningkatan produksi ASI pada ibu nifas pada kategori "140-200 gram" sebanyak 15 orang $(88,2 \%)$ dan distribusi frekuensi terendah pada kategori " $<140$ gram" sebanyak 2 orang $(11,8 \%)$, sedangkan frekuensi tertinggi kelompok kontrol pada kategori " $<140$ gram" sebanyak 14 orang $(82,4 \%)$ dan distribusi frekuensi terendah pada kategori "140-200 gram" sebanyak 3 orang $(17,6 \%)$.

Produksi ASI dan payudara yang membesar selain disebabkan oleh hormon prolactin juga disebabkan oleh human chorionic somatomammotropin (HCS) atau human placental lactogen (HPL) yaitu hormon peptida yang dikeluarkan oleh plasenta. Peningkatan Produksi ASI pada pemberian ASI eksklusif ditandai dengan berat badan bayi baru lahir mengalami kenaikkan berat badan sekitar 140-200 gram perminggu (Sutanto, A.V 2019).

Menurut teori Widiyanti (2014) dalam Rahayuningsih, (2016), perawatan yang efektif untuk memperbanyak produksi ASI antara lain dengan melakukan perawatan payudara atau breastcare dengan menjaga kebersihan dan massage (memijat) payudara, senam payudara, pijat oksitosin dan dukungan suami. Perawatan payudara bertujuan untuk melancarkan sirkulasi darah dan mencegah tersumbatnya saluran produksi ASI sehingga memperlancar pengeluaran ASI.

ASI merupakan nutrisi yang terbaik untuk bayi usia 0 sampai 2 tahun. Pada dua 
tahun pertama kehidupan, merupakan periode emas (golden period) pertumbuhan dan perkembangan anak, sehingga ibu harus memastikan bahwa nutrisi yang diberikan merupakan nutrisi yang terbaik untuk sang buah hati. ASI mengandung nutrient (zat gizi) dan faktor protektif (pelindung) yang menjamin status gizi bayi baik. Salah satu cara yang dapat membantu ibu meningkatkan produksi ASI dan mengurangi stres laktasi ibu adalah dengan melakukan metode BASOKU (Astriyani, 2018).

Peningkatan produksi ASI dengan memperhatikan pola makan seperti makan tepat waktu dan mengkonsumsi makanan secukupnya seperti sayuran, kacang-kacangan, daging, susu, buahbuahan, dan air putih (Permatasari, 2015).

Menurut asumsi peneliti, pada ibu nifas yang diberikan metode BASOKU dan pola makan lebih banyak mengalami peningkatan berat badan bayi pada kategori 140-200 gram karena metode BASOKU dan pola makan efektif dapat meningkatan produksi ASI pada ibu nifas, karena menimbulkan rasa nyaman bagi ibu, sehingga ibu menjadi rileks saat pemberian ASI dan produksi ASI semakin meningkat. Pola makan yang sehat dan baik juga dapat meningkatkan produksi ASI bagi ibu menyusui.

\section{Perbedaan Penggunaan Metode BASOKU dan Pola Makan terhadap Peningkatan Produksi ASI pada Ibu Nifas}

Berdasarkan hasil analisis bivariat dapat diketahui bahwa adanya perbedaan peningkatan produksi ASI pada ibu nifas yang menggunakan metode BASOKU dan Pola Makan dengan yang tidak menggunakan metode BASOKU dan pola makan dengan nilai $p$-value 0.000 .

Hal ini sesuai dengan teori Astiriyani, dkk (2018), beberapa upaya yang dapat dilakukan ibu sendiri untuk mengurangi stress laktasi adalah dengan melakukan olahraga teratur seperti yoga dan senam, memperbaiki pola tidur ibu dan memenuhi asupan makanan yang baik bagi ibu menyusui. Salah satu cara yang dapat membantu ibu meningkatkan produksi ASI dan mengurangi stres laktasi ibu adalah dengan melakukan metode BASOKU.

Hasil penelitian ini juga sesuai dengan penelitian terdahulu yang dilakukan Aziziah melakukan penelitian dengan judul "Penggunaaan Metode BASOKU terhadap Produksi Air Susu Ibu (ASI) di Puskesmas Jepang Kabupaten Kudus tahun 2019". Jenis penelitiannya adalah quasi eksperimen dengan rancangan pre test post with control design. Dari penelitian tersebut didapatkan bahwa penggunaan kombinasi metode BASOKU efektif terhadap peningkatan produksi ASI dengan nilai $p$-value $=0.000$.

Sesuai pula dengan penelitian yang dilakukan oleh Asih tentang Pengaruh Pijat Oksitosin terhadap produksi ASI pada ibu nifas dengan jenis penelitian experimental. Dari penelitian ini dapat disimpulkan bahwa ada pengaruh signifikan antara pijat oksitosin terhadap produksi ASI pada ibu post partum dengan nilai $p$-value $0.037<0,05$.

Penelitian ini sesuai dengan yang dilakukan oleh Novira \& Nindiya (2016) tentang hubungan dukungan suami dengan pemberian ASI eksklusif di Kecamatan Kademangan Kabupaten Blitar. Hasil penelitian diperoleh bahwa dukungan suami lebih besar peluangnya $(27,1 \%)$ terhadap pemberian ASI eksklusif dibandingkan suami yang tidak mendukung $(5,6 \%)$. Walaupun uji korelasi spearman menunjukkan tidak terdapat hubungan yang signifi kan antara dukungan dengan pemberian ASI eksklusif. Ibu yang mendapat dukungan dari suami memiliki proporsi yang lebih besar memberi ASI eksklusif dibandingkan dengan yang tidak mendapatkan dukungan suami meskipun secara statistik tidak berhubungan secara signifi kan. 
Penelitian yang dilakukan oleh Sanima, dkk (2017) tentang hubungan pola makan terhadap produksi ASI pada ibu menyusui di Posyandu Mawar Kelurahan Tlogomas Kecamatan Lowokwaru Kota Malang. Hasil penelitian membuktikan pola makan ibu menyusui lebih dari separuh $(66,7 \%)$ masuk kategori baik dan produksi ASI ibu menyusui lebih dari separuh $(60,0 \%)$ masuk kategori sangat baik. Hasil korelasi spearmen rank didapatkan p-value $=(0,002)<(0,050) \quad$ sehingga dapat disimpulkan bahwa ada hubungan pola makan dengan produksi ASI pada ibu menyusui.

Metode BASOKU (breastcare, pijat oksitosin dan dukungan suami) yaitu kombinasi metode untuk membantu produksi ASI dengan cara pemijatan payudara atau breastcare, pijat oksitosin pada tulang belakang untuk mengeluarkan hormon oksitosin sehingga merangsang produksi ASI lebih banyak dan ditambah dengan dukungan suami dengan memberikan dukungan psikis, membantu melakukan breastcare dan pijat oksitosin. Dengan adanya dukungan suami akan menimbulkan rasa nyaman bagi ibu menyusui, sehingga ibu menjadi rileks saat pemberian ASI dan produksi ASI semakin meningkat (Aziziah \& Nisak, 2019).

Pola makan adalah sebagai karateristik dari kegiatan yang berulang kali dari individu dalam memenuhi kebutuhan akan makanan, sehingga kebutuhan. fisiologis, sosial dan emosionalnya dapat terpenuhi (Sulistyoningsih, 2011).

Hormon prolaktin berkaitan dengan nutrisi ibu, semakin asupan nutrisinya baik maka produksi yang dihasilkan juga banyak, untuk mengeluarkan asi diperlukan hormon oksitosin yang kerjanya dipengaruhi oleh proses isapan bayi semakin puting susu dihisap oleh bayi maka semakin banyak pula pengeluaran ASI (Jannah, 2012).
Menurut asumsi peneliti kombinasi metode BASOKU dan pola makan sangat efektif untuk melancarkan produksi ASI. Perawatan payudara dan pijat oksitosin merupakan salah satu solusi untuk mengatasi ketidaklancaran produksi ASI. Pijat oksitosin membuat ibu merasa nyaman, santai dan tidak kelelahan dapat membantu merangsang pengeluaran hormon oksitosin dan ASI pun cepat keluar dan dengan adanya dukungan suami akan menimbulkan rasa nyaman bagi ibu menyusui, sehingga ibu menjadi rileks saat pemberian ASI dan produksi ASI semakin meningkat. Pola makan yang sehat dan baik juga dapat meningkatkan produksi ASI bagi ibu menyusui.

Saat melakukan penelitian tidak ada kendala khusus karena ibu nifas sudah bersedia untuk menjadi responden hanya saja penelitian dilakukan sesuai dengan protokol kesehatan sesuai dengan keadaan pandemi sekarang misalnya dengan mengunakan masker dan sering mencuci tangan.

\section{KESIMPULAN}

Dari hasil penelitian penggunaan kombinasi metode BASOKU dan pola makan terhadap peningkatan produksi ASI pada ibu nifas di PMB Santi Yosina Amd.Keb Kecamatan Syamtalira Bayu Kabupaten Aceh Utara didapatkan ada perbedaan antara penggunaan kombinasi metode BASOKU dan pola makan terhadap peningkatan produksi ASI pada ibu nifas dengan nilai $p$ value $0.000<$ 0.05 .

\section{UCAPAN TERIMAKASIH}

Ucapan terimakasih dalam penelitian ini untuk responden penelitian, yang telah bersedia menjadi sampel dalam penelitian ini serta bersedia meluangkan waktunya pada saat observasi dan penyebaran kuisioner dan PMB Santi Yosina 
Amd.Keb Kecamatan Syamtalira Bayu, yang telah memberikan ijin penelitian.

\section{DAFTAR PUSTAKA}

Aziziah \& Nisak. (2019). Penggunaan Kombinasi Metode BASOKU terhadap produksi Air Susu Ibu (ASI). Kudus : Universitas Muhammadiyah. Terdapat Pada : h://ejournal.stikesmuhgombong.a c.id (Diakses 5 Oktober 2020).

Astriyani, E. dkk. (2018). Pengaruh Hynobreastfeeding pada Ibu Hamil Trimester III terhadap Kecukupan ASI pada Bayi I Puskesmas Kahuripan Kecamatan Tawang Kota Tasikmalaya Tahun 2018. Jawa Barat : Poltekkes Kemenkes Tasikamalaya. Terdapat Pada : http://ejurnal.stikesrespatitsm.ac.id/index.php/bidkes/article /view/86. (Diakses 7 Oktober 2020).

Jannah, N. (2012). Buku Ajar Asuhan Kebidanan: Kehamilan. Yogyakarta: Andi OF SET.

Kumala, F \& Rini, S. (2017). Panduan Nifas dan Evidance Based Practice. Yogyakarta : Deepublish.

Permatasari, E. (2015). Hubungan Asupan Gizi Dengan Produksi Asi Pada Ibu Yang Menyusui Bayi Umur 0-6 Bulan Di Puskesmas Sewon I Bantul Yogyakarta. Skripsi: Sekolah Tinggi Ilmu Kesehatan 'Aisyiyah Yogyakarta.

Sari, L.P. (2017). Rahasia Sukses Mengoptimalkan Produksi ASI. Yogyakarta : Fitramaya.
Sulistyoningsih, H. (2011). Gizi untuk Kesehatan Ibu dan Anak.Yogyakarta: Graha Ilmu.

Sanima, dkk. (2017). Hubungan Pola Makan Terhadap Produksi ASI Pada Ibu Menyusui Di Posyandu Mawar Kelurahan Tlogomas Kecamatan Lowokwaru Kota Malang. Nursing News Volume 2 Nomor 3 tahun 2017. Terdapat Pada : https://123dok.com/document/yd9 ge1lz-hubungan-produksimenyusui-posyandu-kelurahantlogomas-kecamatanlowokwaru.html. (Diakses 5 Oktober 2020).

Sutanto, A.V. (2019). Asuhan Kebidanan Nifas dan Menyusui Teori dalam Praktik Kebidanan Profesional. Yogyakarta : Pustaka Baru Press.

Widiyanti, A.F. dkk. (2014). Perbedaan Antara Dilakukan Pijat Oksitosin dan Tidak Dilakukan Pijat Oksitosin Terhadap Produksi ASI pada Ibu Nifas di Wilayah Kerja Puskesmas Ambarawa. Semarang : Akbid Ngudi Waluyo Ungaran. Terdapat Pada https://doi.org/10.26911/thejmch. 2016.01.02.05. (Diakses 5 Oktober 2020). 